IZA DP No. 5577

Unemployment Insurance Savings Accounts in Latin America: Overview and Assessment

Ana M. Ferrer

W. Craig Riddell

March 2011 


\title{
Unemployment Insurance Savings Accounts in Latin America: Overview and Assessment
}

\author{
Ana M. Ferrer \\ University of Calgary \\ W. Craig Riddell \\ University of British Columbia \\ and IZA
Discussion Paper No. 5577
March 2011 \\ IZA \\ P.O. Box 7240 \\ 53072 Bonn \\ Germany \\ Phone: +49-228-3894-0 \\ Fax: +49-228-3894-180 \\ E-mail: iza@iza.org
}

Any opinions expressed here are those of the author(s) and not those of IZA. Research published in this series may include views on policy, but the institute itself takes no institutional policy positions.

The Institute for the Study of Labor (IZA) in Bonn is a local and virtual international research center and a place of communication between science, politics and business. IZA is an independent nonprofit organization supported by Deutsche Post Foundation. The center is associated with the University of Bonn and offers a stimulating research environment through its international network, workshops and conferences, data service, project support, research visits and doctoral program. IZA engages in (i) original and internationally competitive research in all fields of labor economics, (ii) development of policy concepts, and (iii) dissemination of research results and concepts to the interested public.

IZA Discussion Papers often represent preliminary work and are circulated to encourage discussion. Citation of such a paper should account for its provisional character. A revised version may be available directly from the author. 


\section{ABSTRACT \\ Unemployment Insurance Savings Accounts in Latin America: Overview and Assessment ${ }^{*}$}

The unemployment protection systems that exist in most Latin American economies are generally considered inadequate in terms of providing insurance to workers. They may also encourage stratified labor markets and impose barriers to the employee's mobility and the firm's adjustment to changing labor market conditions. In addition, some of these systems involve high administrative and monitoring costs and may create additional adverse effects that induce higher unemployment rates and longer duration of unemployment and promote informal labor markets. Recently, research effort and policy interest has turned to Unemployment Insurance Savings Accounts (UISAs) as an alternative to traditional systems of unemployment insurance. UISAs are schemes of individual mandatory savings. Therefore, they smooth income over an individual's life cycle rather than pooling unemployment risk over the total working population at a point in time. This form of unemployment insurance diminishes the moral hazard problems associated with traditional insurance methods. However, it presents problems of its own. First, it is questionable that these systems provide adequate protection against unemployment risk. Additionally, their effects on the promotion of informal labor markets and their administrative costs are yet to be determined. Finally, the effectiveness as a form of unemployment insurance depends critically upon the performance and credibility of the financial institutions managing the funds. This paper examines the experience of Latin American countries that use UISAs, with the hope of highlighting the problems of the system and identifying areas for future theoretical and empirical work. The overall effect of UISAs depends on a vast array of specific country characteristics and program parameters. The way the system is implemented, existing labor regulation, the extent of the informal economy and the scope for collusive behavior greatly influence the success of these programs. This calls for a more extensive research effort in the area.

JEL Classification: J65, J08

Keywords: unemployment insurance, moral hazard, severance pay, Latin America, labor markets

Corresponding author:

W. Craig Riddell

Department of Economics

University of British Columbia

997-1873 East Mall

Vancouver, BC V6T $1 Z 1$

Canada

E-mail: criddell@interchange.ubc.ca

\footnotetext{
* An earlier version of this paper appeared as World Bank SP Discussion Paper No. 910 (June 2009). We thank Milan Vodopivec and a referee for helpful comments.
} 


\section{Introduction}

A variety of economic shocks have hit Latin American countries since the end of the 1990's. The effects of these shocks upon the labor market have been severe and have re-awakened a long standing debate between the need for employment stability and the need for flexible labor markets. For firms, extensive labor regulation implies a costly adjustment to economic changes, loss of competitiveness and slower economic recoveries. ${ }^{1}$ On the other hand, in the absence of adequate mechanisms of income support, flexible labor markets leave workers unprotected to face economic downturns. Additionally, poor labor stability may have undesirable effects on human capital accumulation and labor productivity.

Many Latin American countries seek in labor market flexibility a way out of improving economic performance. In these circumstances, providing adequate income support for the affected workers becomes most important. Traditionally, most Latin American countries have protected the unemployed through a combination of high severance payments and/or low unemployment insurance or subsidies. Both theoretical and empirical research shows that these systems offer low coverage, benefit workers from the formal sector only, impede labor mobility and technological adjustment by the firms, and provide incentives for the creation of informal job relations. ${ }^{2}$

The unemployment protection systems that exist in most Latin American economies are generally considered inadequate in terms of providing insurance to workers and are prone to generate stratified labor markets. Recently, research effort and policy interest has turned to Unemployment Insurance Savings Accounts (UISAs) as an alternative to traditional systems of unemployment insurance. UISAs are schemes of individual mandatory savings that smooth income over an individual's life cycle time rather than pooling unemployment risk over the total working population at a point in time. Although this form of unemployment insurance diminishes the moral hazard problems associated with traditional insurance methods, it presents

\footnotetext{
${ }^{1}$ The effects of labor market regulation on various aspects of employment and unemployment in Latin America have been studied by Barros and Corseuil (2004), MacIsaac and Rama (2000), Mondino and Montoya (2000), Saavedra and Torero (2000), and Marquez and Pages (1998).

${ }^{2}$ See Blanchard and Tirole (2008), Heckman and Pages (2000), Blondal and Pearson (1995).
} 
problems of its own. This paper examines the experience of Latin American countries that use UISAs, with the hope of highlighting the problems of the system and identifying areas for future theoretical and empirical work. We conclude that the overall effect of UISAs depends on a vast array of specific country characteristics and program parameters. The way the system is implemented, existing labor regulation, the extent of the informal economy and the scope for collusive behavior greatly influence the success of these programs. This calls for a more extensive research effort in the area.

The paper is organized as follows. The next section discusses the potential advantages of UISA's. Section 3 describes the UISA systems currently in place in Latin America and analyzes some of the issues concerning UISA's that have arisen in the light of these countries' experiences. Section 4 concludes.

\section{Potential Advantages of UISA's}

In the context of the existent high levels of unemployment in most Latin American countries, a review of the current and alternative systems of unemployment protection is called for. Recently, research effort and policy interest has turned to UISAs as an alternative to traditional systems of unemployment insurance. UISAs are schemes of mandatory savings. The basic design of these systems is as follows. Workers and/or firms are required to make regular deposits to individual accounts. In the event of unemployment, the worker can withdraw funds from his account to support the transition toward another job. This system has the potential advantage of making workers internalize the cost of unemployment benefits, hence avoiding traditional moral hazard problems present in most insurance schemes. In general, this system does not adversely affect the incentives for job search as does conventional unemployment insurance. It has, however, potential adverse effects that have to be addressed. Theoretical studies by Orszag et al. (1999) and Stigliz and Yun (2002) indicate that unless savings accounts are comprehensive -- that is, they become pension funds upon retirement -- workers will have incentives to withdraw from the labor force before retirement to claim their accumulated savings. These studies also suggest that, as long as the various risks faced by a given person are not perfectly correlated, integration of 
the various social insurance programs intended to deal with these individual risks will also be welfare improving.

UISA's have been assessed against more traditional systems of unemployment insurance (UI) ${ }^{3}$. Because UISA's are individual accounts, the moral hazard problem present in UI programs is expected to vanish. Workers should fully internalize the cost of remaining unemployed and have greater incentives towards re-employment. This is an important aspect of UISA's given the limited monitoring capacity of developing countries. Because the two systems require different degrees of infrastructure, they are generally suitable for economies at different levels of development. However, most of the debate over UISA's focuses on its advantages versus severance pay, the most common form of unemployment protection in Latin America ${ }^{4}$. UISAs do offer some of the same advantages that severance pay does ${ }^{5}$. Severance pay constitutes a lump sum -- the magnitude of which usually depends on job tenure -- collected upon job separation. Consequently, it should not affect job search effort. It is also unlikely to reduce effort exerted on the job, since misconduct at work often precludes severance pay. Therefore, both UISAs and severance pay may avoid moral hazard problems on the part of the worker. The main difference between both systems, however, is that severance pay creates additional moral hazard problems on the part of the firm that are not present in UISAs. Because, in the case of severance pay, payments are only made at the end of the labor contract, and may reach at the time of liquidation considerable size, firms have incentives to try to avoid payment (Kluger, 2001). Additionally, there is not, in general, a legal requirement for the firms to maintain enough reserves to support this obligation. This creates liquidity problems when the firms need to make substantial labor adjustments. UISAs, on the other hand do not create such incentive problems because smaller payments are made regularly to the individual accounts. Hence, the main advantage of UISAs relative to severance pay is to avoid the firm moral hazard problem and to guarantee payments to the worker in the event of unemployment. An additional distinction between the two systems is that UISAs qualifies as a delayed payment, rather than as a firing cost, which is the case of severance pay. This has important consequences in terms of creating a

\footnotetext{
${ }^{3}$ See Vodopivec and Raju (2002)

${ }^{4}$ See Parsons (2010) for a discussion of the differences between UISA's and Severance Pay income protection systems for workers permanently separated from their jobs.

${ }^{5}$ For an overview of the severance pay system around the world and in Latin America see Holzman, Pouget, Vodopivec and Weber (2011) and Jaramillo and Saavedra (2005).
} 
more flexible labor market without lowering income protection. The same incentives that may induce a firm to avoid the payment of a large severance package may prevent it from dismissing unproductive workers or (formally) hiring additional workers.

One of the major uncertainties regarding an UISA system concerns its capacity to provide sufficient coverage and adequacy of benefits against unemployment risk. Since, in the event of unemployment, workers withdraw funds from a personal account rather than from a common pool of resources, benefits may not be adequate for individuals who experience frequent or longlasting spells of unemployment. For this reason, UISA systems are not usually conceived as the sole form of unemployment protection. Alternatively, they may contain additional features such as limits on the withdrawal of funds or government contributions to a separate pool of funds, which would alleviate these situations. The most common theoretical proposal includes a combination of self-insurance with public insurance. In these models, workers may borrow from the government in the event that their own unemployment account balance becomes negative. Model simulations seem to offer hope that such systems will indeed be viable (Feldstein and Altman 2007 and Vodopivec and Rejec, 2001). In line with these models, Chile has implemented a UISA system that also finances, through employer and government contributions, a common unemployment fund (Fondo Solidario). Chilean workers with insufficient balances in their accounts can borrow against the Solidarity Fund.

An additional issue regarding the coverage of UISAs systems arises when we consider the extent of the informal economy in many Latin American countries. In general, any system that significantly increases the burden of labor costs for employers has the potential to promote informal labor contracts (Lozoya, 1996). Theoretically, UISAs are less prone than other systems to have this effect, since employers' contributions do not usually depend on the length of employment, neither are they necessarily tied to other labor costs. In practice, however, it is important to note that the effects will depend on country specific issues such as: how the UISA system is implemented, its cost relative to the previous program, and how it interacts with other labor regulations. Therefore, country specific case studies are necessary to analyze the effects of UISAs in promoting formal labor contracts. 
Another dimension on which UISAs offer a potential advantage relative to more traditional UI and severance payment systems is that they promise to have relatively low administrative costs. Since, in general, the funds are accessible upon any kind of separation, extensive monitoring is not needed. Additionally, the funds are deposited in individual accounts, in most cases in existent financial institutions, which also reduce managing costs. Again, the extent of this advantage depends on country specific factors. A system that combines UISAs with social insurance may still have considerable monitoring costs. In addition, if benefits are contingent upon the type of dismissal, other costs, such as litigation costs, may have to be considered. ${ }^{6}$ It is worth mentioning that, since funds in unemployment accounts become pension funds upon retirement, UISAs may provide a foundation for developing individual pension plans. Although this aspect may not be apparent right now, given the small size of the balances generally held in these accounts, it may prove important in the face of growing concern about the sustainability of public pension funds. As an alternative to company pension plans, UISAs have the advantage of being fully portable (therefore, not restricting worker's mobility) and not having higher administrative costs.

A final consideration with respect to UISAs involves the managerial capability and the credibility of the institutions managing the funds. If the managing insititution does not generate enough real return on the deposits, workers' valuation of the UISA funds will be low. Because of the illiquid nature of the funds, workers with large holdings will have incentives to look for alternative ways of accessing the account. In particular, if the worker's valuation of the fund becomes lower than the employer's cost of the payments, there will be incentives for informal agreements that may benefit both parties. Evidence of this behavior has been documented for Brazil where workers may provoke their own dismissal (and posterior rehiring) in order to access the fund (Gil et. al., 2000, and Barros, Corseuil and Foguel, 1999). This type of collusive behavior is difficult to anticipate. It may originate from the lack of credibility of the institutions that are managing the funds, but also from the severity of liquidity constraints for the covered population. The particular form of collusive behavior is also likely to be country specific, depending on the interaction of the UISA system with existing labor regulations. In this context, it is worth mentioning that other institutional factors may also affect the effectiveness of the

\footnotetext{
${ }^{6}$ This is the case in Brazil. See Camargo (2002).
} 
system. One example is the case of Peru, where the government has authorized several withdrawals from the individual accounts for purposes other than unemployment protection. ${ }^{7}$ As a result, unemployment protection has become limited or even non-existent for those workers who decide to withdraw funds. Although these measures were deemed temporary, the Peruvian government is experiencing difficulties going back to the UISA system of mandatory savings, since workers have been enjoying a form of wage increase from the "temporary" measures that is difficult to give up.

Overall, UISAs have the potential of overcoming some of the worst features of traditional systems of unemployment protection, reducing moral hazard, lowering administrative costs (with respect to unemployment insurance), reducing firing costs and avoiding firms' liquidity issues (with respect to severance payments). Theoretically, they are also likely to promote formal labor markets. However, the system needs to be upgraded with additional features if it is to provide adequate coverage. This, in turn, may limit the advantages mentioned before. The overall effect of UISAs depends on a vast array of specific country characteristics and program parameters. Examination of the existing UISA systems is a first step in this direction. By describing the experience of Latin American countries that use UISAs, we hope to offer light on the common problems of the system and suggest possible directions for future theoretical and empirical work.

\section{Unemployment Insurance Savings Accounts in Latin America}

\section{Overview}

Offering an overview of UISA's in Latin America presents several challenges. It is often difficult to obtain comparable information on the performance of the institutions under analysis. In the case of Latin America, some programs have been in place for a relatively short time (Chile, Ecuador) while others have more than twenty years of history (Brazil, Colombia, Peru or Panama). In some countries, all dependent workers have the right to be covered by the system of individual accounts. Yet, in Argentina UISA's only cover construction workers. This variation

\footnotetext{
${ }^{7}$ Peru, Decreto de Urgencia 67-2002 (to repay loans garanteed with CTS) and Decreto de Urgencia 19-2002 (to
} 
across programs limits the amount of information available to researchers. Additionally, accounting methods also vary across countries, making comparisons more difficult. For instance, Brazil publishes only the number of active accounts, which may not correspond with the number of workers covered by the system, as accounts are linked to jobs rather than to individuals.

We summarize the main characteristics of UISA's in Table 1.

As mentioned, UISAs are mandatory savings schemes in which employers (and in the case of Chile, workers as well) contribute on a regular basis a fraction of the monthly wage towards a special individual account. In general, upon separation workers can access the totality of the funds. In all the cases examined here, the fund is available to the worker upon retirement or to the inheritors, in the case of death. Table 1 shows the main features of the UISAs in Latin America: the year the program was introduced, the type of worker covered, the amount of contributions, eligibility requirements to access the funds, income protection benefits, other benefits derived from the funds, whether the system provides social insurance, and the type of institution that manages the funds. Most countries, except Argentina, Brazil and Peru, cover all dependent workers (employees). Contributions are mostly made by employers and are generally around one month's wages per year, although they may range from one week's wages per year (Panama) to a maximum of $12 \%$ of the monthly wage in Argentina. In Chile the government also makes contributions to the fund. Most countries allow employees to make voluntary contributions, whereas employee contributions are required in Chile. In terms of the prerequisites to collect the funds, some countries, like Brazil and Ecuador, make the payment conditional upon the type of separation. This restriction has the potential to increase monitoring and administrative costs (Camargo (2002)). It may also contribute to employer-employee collusive behavior regarding how separations are "labeled". Such behavior has been extensively documented for Brazil (Barros, Corseuil and Foguel, 1999). In addition, Chile, Ecuador and Venezuela require a minimum of contributions or tenure in order to access the funds. Regarding the amounts available in case of job separation, most countries allow access to the total balance of the fund. However, Chile and Ecuador, which have a system closer to the original unemployment insurance saving account model, limit the benefits that can be collected at one incentive domestic demand). 
given time. This feature further reduces the incentives for collusive behavior mentioned above at the cost of increasing administrative costs.

An additional issue concerning the adequacy of the benefits arises from the severity of liquidity constraints. Since UISAs may be imposing mandatory savings on a potentially credit constrained population with perverse effects on family expenditures and investments, most programs (except Chile, Ecuador and Venezuela) allow partial withdrawals from the fund to finance human capital investments and to pay for housing or health expenses. The effect that these "exceptions" have on the insurance role of the individual funds is yet to be examined. In Peru, for instance, the increased allowances of fund withdrawal are threatening the purpose of the severance fund as a source of income protection against unemployment.

How good are UISAs in providing income protection in the event of unemployment? One of the main problems of a pure UISA system is that it forgoes the redistributive effects available with a system that pools the unemployment risks of all the working population. Because of the concentration of unemployment among certain groups of the population, UISAs may not provide adequate benefits for temporary workers or those with low incomes. This creates the problem of providing alternative sources of income for workers with insufficient funds in their accounts. Of all the countries, Chile is the only one that offers social protection within the individual account system, through the Solidary Fund. Ecuador is moving towards a system based only on individual accounts, but it is currently a mixed system, where part of the population still withdraws funds from a common pool. In other countries, additional income sources may be available from other programs. 
Table 1. UISA Characteristics

\begin{tabular}{|c|c|c|c|c|c|c|c|}
\hline $\begin{array}{l}\text { Country (Year of } \\
\text { introduction) }\end{array}$ & Coverage & Contributions & $\begin{array}{c}\text { Eligibility } \\
\text { Requirements }\end{array}$ & Unempl. Benefits & Other Benefits & Social Insurance & Funds Mngmt \\
\hline $\begin{array}{l}\text { Argentina } \\
\text { (1975) }\end{array}$ & $\begin{array}{l}\text { Construction } \\
\text { Workers }\end{array}$ & $\begin{array}{l}\text { Employers: } 12-8 \% \text { m. } \\
\text { wage }\end{array}$ & $\begin{array}{l}\text { Proof of } \\
\text { dismissal }\end{array}$ & $\begin{array}{l}\text { Balance upon } \\
\text { separation }\end{array}$ & -- & NO & $\begin{array}{l}\text { Banking } \\
\text { Institutions }\end{array}$ \\
\hline Brazil (1989) & $\begin{array}{l}\text { Dependent } \\
\text { workers not } \\
\text { covered } \\
\text { elsewhere } \\
\end{array}$ & Employers: 8\% m. wage. & $\begin{array}{l}\text { Contingent on } \\
\text { type of separation }\end{array}$ & $\begin{array}{l}\text { Balance upon } \\
\text { separation. }\end{array}$ & $\begin{array}{l}\text { Partial withdrawal } \\
\text { allowed for housing or } \\
\text { health expenses. }\end{array}$ & NO / Other Programs & Government \\
\hline Chile (2002) & $\begin{array}{l}\text { Dependent } \\
\text { workers }\end{array}$ & $\begin{array}{l}* * \text { Employees: } 0.6 \% \text { m. } \\
\text { wage Employers: } 2.4 \% \\
\text { m. wage } \\
\text { Gov. Contributions }\end{array}$ & $\begin{array}{l}\text { Minimum } 12 \\
\text { contributions }\end{array}$ & $\begin{array}{l}1 \mathrm{~m} . / \text { year (up to } 5 \\
\text { m.) Decreasing } \\
\text { benefits with min } \\
\text { and max }\end{array}$ & -- & $\begin{array}{l}\text { Min.benefits } \\
\text { guaranteed with the } \\
\text { Solidarity Fund. (up } \\
\text { to } 2 \text { withdrawals } \\
\text { every } 5 \text { years) }\end{array}$ & $\begin{array}{l}\text { Recognized } \\
\text { Financial Inst. } \\
\text { (exclusive } \\
\text { dedication) }\end{array}$ \\
\hline $\begin{array}{l}\text { Colombia } \\
\text { (1990) }\end{array}$ & $\begin{array}{l}\text { Dependent } \\
\text { workers }\end{array}$ & $\begin{array}{l}\text { Employers: } 9.3 \% \text { m. } \\
\text { wage. }\end{array}$ & Proof of dismissal & $\begin{array}{l}\text { Balance upon } \\
\text { separation. }\end{array}$ & $\begin{array}{l}\text { Partial withdrawal } \\
\text { allowed. Funds can } \\
\text { guarantee some house } \\
\text { loans }\end{array}$ & NO / Other Programs & $\begin{array}{l}\text { Recognized } \\
\text { Financial Inst. } \\
\text { (exclusive } \\
\text { dedication) }\end{array}$ \\
\hline $\begin{array}{l}\text { Ecuador } \\
\text { (Mixed 2001) }\end{array}$ & $\begin{array}{l}\text { Dependent } \\
\text { workers }\end{array}$ & $\begin{array}{l}\text { Employer: } 1 \text { m. wage / } \\
\text { year to individual } \\
\text { accounts (monthly } \\
\text { contribution). }\end{array}$ & $\begin{array}{l}\text { Involuntary } \\
\text { unemployment } \\
\text { Min } 48 \text { deposits } \\
1 \text { year tenure } \\
\end{array}$ & $\begin{array}{l}\text { Balance upon } \\
\text { separation / } 3 \\
\text { times the avg wage } \\
\text { in previous year } \\
\end{array}$ & -- & NO / Other Programs & $\begin{array}{l}\text { Recognized } \\
\text { Financial Inst. } \\
\text { (exclusive } \\
\text { dedication) } \\
\end{array}$ \\
\hline Panama (1972) & $\begin{array}{l}\text { Dependent } \\
\text { workers }\end{array}$ & $\begin{array}{l}\text { Employer: } 1 \text { w. wage / } \\
\text { year + 5\% compensation } \\
\text { Employee: voluntary }\end{array}$ & $\begin{array}{l}\text { Additional } \\
\text { compensation } \\
\text { contingent on } \\
\text { type of separation }\end{array}$ & $\begin{array}{l}\text { Balance upon } \\
\text { separation }\end{array}$ & $\begin{array}{l}\text { Partial withdrawal } \\
\text { allowed for housing, } \\
\text { education or health } \\
\text { expenses }\end{array}$ & $\begin{array}{l}\text { NO / risk pooling } \\
\text { within firms }\end{array}$ & $\begin{array}{l}\text { (collective) Trust } \\
\text { fund with } \\
\text { approved financial } \\
\text { institution }\end{array}$ \\
\hline Peru (1991) & $\begin{array}{l}\text { Private workers } \\
\text { not covered } \\
\text { elsewhere }\end{array}$ & $\begin{array}{l}\text { Employers: } 2 \text { deposits of } \\
1 / 2 \text { m. wage }\end{array}$ & Proof of dismissal & $\begin{array}{l}\text { Balance upon } \\
\text { separation }\end{array}$ & $\begin{array}{l}50 \% \text { withdrawal } \\
\text { allowed. Additional } \\
\text { withdrawal authorized } \\
\text { occasionally }\end{array}$ & $\mathrm{NO}$ & $\begin{array}{l}\text { Banking } \\
\text { Institutions }\end{array}$ \\
\hline $\begin{array}{l}\text { Venezuela } \\
\text { (1997) }\end{array}$ & $\begin{array}{l}\text { Dependent } \\
\text { workers }\end{array}$ & $\begin{array}{l}\text { Employer: } 5 \text { d wage/ } \\
\text { month. Increases with } \\
\text { tenure. Max } 30 \text { d } \\
\text { wage/year }\end{array}$ & 3 months tenure & $\begin{array}{l}\text { Balance upon } \\
\text { separation }\end{array}$ & -- & NO / Other Programs & $\begin{array}{l}\text { Recognized } \\
\text { Financial Inst. / } \\
\text { Employer }\end{array}$ \\
\hline
\end{tabular}

** Minimum and maximum contributions 
Another source of difference among countries relates to the administration of the funds. Most programs establish special financial institutions -- or create special regulations governing existing institutions -- whose sole function is the managing of the unemployment / severance fund. Other countries, like Argentina or Peru, allow the funds to be deposited in the regular banking system (and instead regulate the type of deposit). In Brazil the government operates the fund, while Panama gives the employer discretion about the choice of the managing institution. Venezuela has opted for a mixed system for the administration of the severance fund.

The rest of this section offers a detailed review of the features and operation of the UISA systems currently in place in Latin America. It also goes on to analyze some of the issues concerning the performance of UISA's that have arisen in the context of different countries' experiences.

\section{Argentina}

Argentina has a form of UISA for construction workers. The Collective Bargaining Agreement for Construction Workers in Argentina (Convenio Colectivo de la Construccion 76/75) refers to a "Fondo de Desempleo for the Construction Industry" (Unemployment Fund for Construction Industry). It establishes that employers must make monthly contributions of 12\% (in the first year) and $8 \%$ (in subsequent years) of the monthly wage. These contributions are deposited in individual accounts in banking institutions and are, presumably, available to the worker upon separation of any kind.

\section{Brazil}

The FGTS (Fundo de Garantia de Tempo do Servicio) was established in 1967. The new Constitution of 1988 brought major changes to labor regulation and unemployment protection in Brazil. In particular, it established that contributions to the FGTS should be placed in individual accounts rather than into a common pool of resources. It also introduced changes in the penalty a firm must pay if it dismisses a worker without just cause. The two concepts are closely related because the penalty is set as a percentage of the value accumulated in the fund. In particular, the 1988 constitution set this penalty for dismissal without just cause from 10 to $40 \%$ of the amount 
accumulated in the worker's account during the length of the contract. ${ }^{8}$ This amount is paid directly to the worker. Additionally, in 2001, the government legislated additional social contributions to the fund in the case of dismissal without just cause. These include $10 \%$ of the deposits accumulated in the FGTS during the contract and 0.5 of the last monthly wage. The purpose of these contributions is to cover the deficit generated by a ruling of the Brazilian Supreme Tribunal of Justice that recognized the worker's right to a monetary adjustment on FGTS accounts between 1988 and 1989. Therefore, these contributions -- although part of the Fund -- do not increase worker's accounts individually.

The fund is built with contributions from the employers that amount to $8 \%$ of the employee's monthly salary ${ }^{9}$, roughly one month of pay per year of work. Individual accounts are associated with specific labor contracts. Therefore, there are as many accounts as labor contracts. These can be classified into two main groups:

- Active Accounts are those that receive regular deposits and are associated with operating labor contracts.

- Inactive Accounts are those that do not receive regular deposits because of the termination of the labor contract under which they were established.

The regulatory organ of the system is the "Conselho Curador", which consists of two employer representatives, two employee representatives and six government officials from various ministries. Its main function is to decide the allocation of the resources. The Ministry of Planification (MPO, Ministerio do Planejamiento e Orcamento) is the supervisor of the program and the CEF (Caixa Economica Federal) operates the fund. The Caixa also keeps a register of historic accounts to facilitate worker's information on all of his labor history.

Table 2 shows the evolution of the number, value and average balance of accounts with a positive balance. The number of active accounts increased by 63\% between 1999 and 2009, while the

\footnotetext{
${ }^{8}$ See Paes de Barros, Corseuil and Bahia (1999) for a complete account of these constitutional changes to labor regulation.

${ }^{9}$ Temporary workers get a contribution of $2 \%$. The severance penalty for dismissal for unjust cause is waived for temporary employees.
} 
value of these accounts almost quadrupled during the same time period. The average balance in 2009 was almost 3,000 Brazil Reais (BRL), approximately 1,840 US\$.

Table 2. FGTS, Number and Value of Accounts

\begin{tabular}{|l|c|c|c|c|c|c|}
\hline & \multicolumn{3}{|c|}{ Active Accounts } & \multicolumn{3}{c|}{ Inactive Accounts } \\
\hline & $\begin{array}{c}\text { Amount } \\
\text { (Th.) }\end{array}$ & $\begin{array}{c}\text { Value } \\
\text { (Mill. BRL) }\end{array}$ & $\begin{array}{c}\text { Avge Balance } \\
\text { (BRL) }\end{array}$ & $\begin{array}{c}\text { Amount } \\
\text { (Th.) }\end{array}$ & $\begin{array}{c}\text { Value } \\
\text { (Mill. BRL) }\end{array}$ & $\begin{array}{c}\text { Avge Balance } \\
\text { (BRL) }\end{array}$ \\
\hline $\mathbf{1 9 9 9}$ & 48,005 & 63,286 & - & 17,858 & 2,623 & - \\
\hline $\mathbf{2 0 0 0}$ & 54,271 & 67,121 & 1,237 & 9,379 & 1,316 & 140 \\
\hline $\mathbf{2 0 0 1}$ & 59,156 & 73,767 & 1,247 & 9,584 & 1,338 & 140 \\
\hline $\mathbf{2 0 0 2}$ & 63,632 & 80,799 & 1,270 & 4,976 & 757 & 152 \\
\hline $\mathbf{2 0 0 4}$ & 55,184 & 99,277 & 1,799 & 646.8 & 350.0 & 541 \\
\hline $\mathbf{2 0 0 6}$ & 55,043 & 125,765 & 2,285 & 15,088 & 3,854 & 255 \\
\hline $\mathbf{2 0 0 9}$ & 78,700 & 235,000 & 2,986 & 7,200 & 1,600 & 222 \\
\hline
\end{tabular}

Source: FGTS Prestacâo de Contas Exercicio 2001, 2000; Relatorio de Gestão (2002, 2004, 2006) $1 \mathrm{BRL}=0.6133$ USD

Upon dismissal without just cause, the worker can access $100 \%$ of the fund including any portion accumulated from previous jobs. However, the worker can also access the fund under the following circumstances:

- Indirect dismissal $^{10}$

- Break-down of contract for reciprocal causes, unavoidable causes, or firm closure

- Termination of the labor contract

\footnotetext{
${ }^{10}$ Indirect dismissal refers to court requests initiated by the employee to be dismissed from his job claiming breach of the labor contract.
} 
- Retirement (individuals older than 70 years of age have automatic access to the Fund), death, disability and specific health issues

- Inactive account for more than 3 years (unemployed or out of the labor force)

- House acquisition or financing of mortgage payments.

Withdrawals for dismissal constitute around two-thirds of all fund removals, while housing withdrawals are approximately $15 \%$. The composition of withdrawals has remained stable between 1999 and 2002, with a slight increase in the value of withdrawals associated with dismissals and a decline in the value of the withdrawals to finance the purchase of a house. The Fund itself has been very active in the financing of housing or home improvement.

Between 1997 and 1999, the Fund experienced liquidity issues (see Figure 1). Part of it could be attributed to the rising unemployment rate experienced at the end of the decade. The year 2000 saw the beginning of a recovery that continued through the decade, lead by the fall of the unemployment rate and the efforts of the Caixa both to recover past credits and to increase the number of accounts.

Figure 1. Liquidity of FGTS (Millions of BRL)

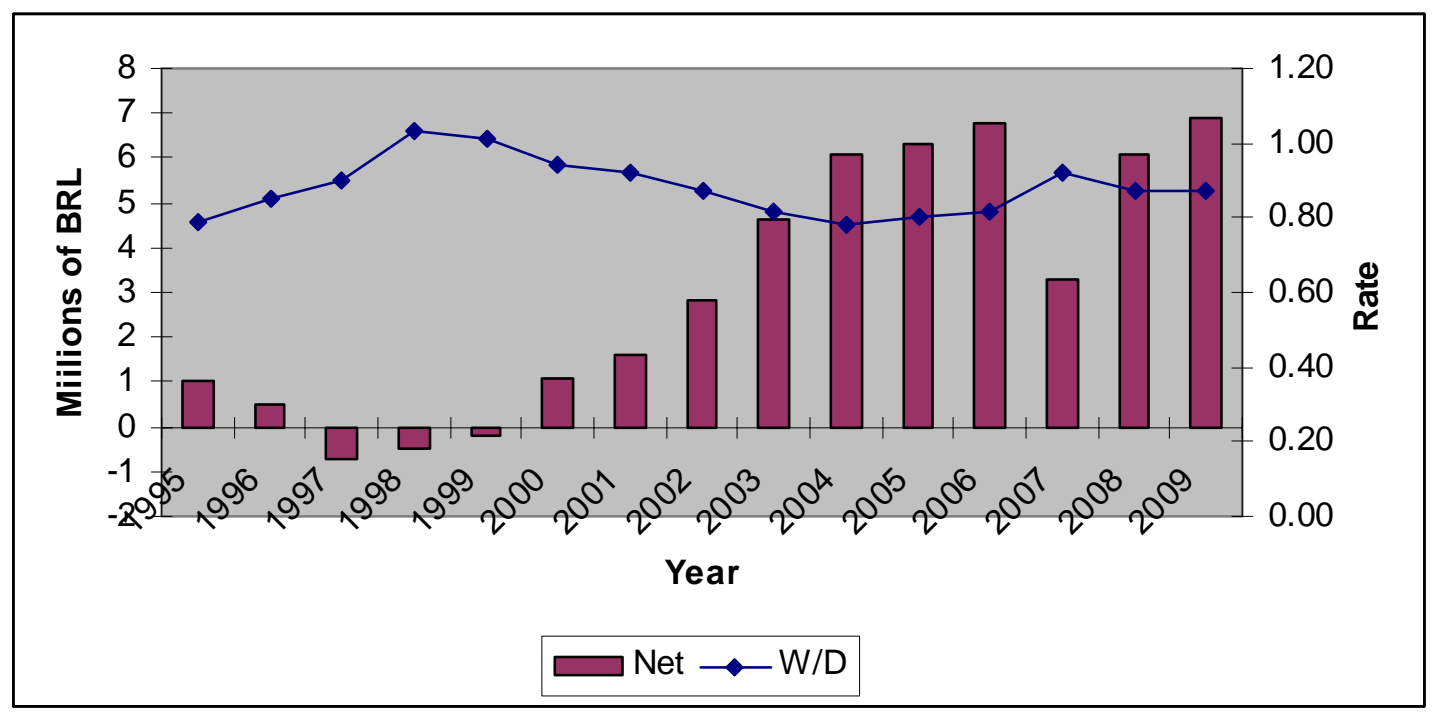

Source: Authors Calculations based on Relatórios de Gestão do FGTS http://www.caixa.gov.br/fgts/relatorios_balancos_fgts.asp\# 


\section{Chile}

Traditionally, unemployment protection in Chile included an unemployment subsidy and severance pay. The first instrument covered workers dismissed for unjust cause and who had 12 months of contributions to any insurance system. This instrument had both low benefits, ranging from 12 to $25 \%$ of the minimum wage, over a maximum period of 12 months, and low coverage, $30 \%$ of the potential beneficiaries. The second instrument covered workers in the event of dismissal for economic reasons. The benefits were one month of wages per year of tenure with an alternative severance payment that could be negotiated after six years of tenure. This form of severance pay was closer in spirit to a UISA system but it covered only a small fraction of unemployed workers. In particular, it did not cover dismissal for reasons other than economic, including retirement, death, and voluntary quits. In addition, since 1991, a system of individual accounts has also been in place for domestic workers (Chilean Labour Code, art. 163-165). Dismissal for any reason entitled domestic workers to a severance payment for the value of the accumulated fund. Employers contributed $4.11 \%$ of the monthly wage to the domestic worker fund for a maximum of eleven years.

\section{Figure 2. Financing of the Chilean Unemployment System}

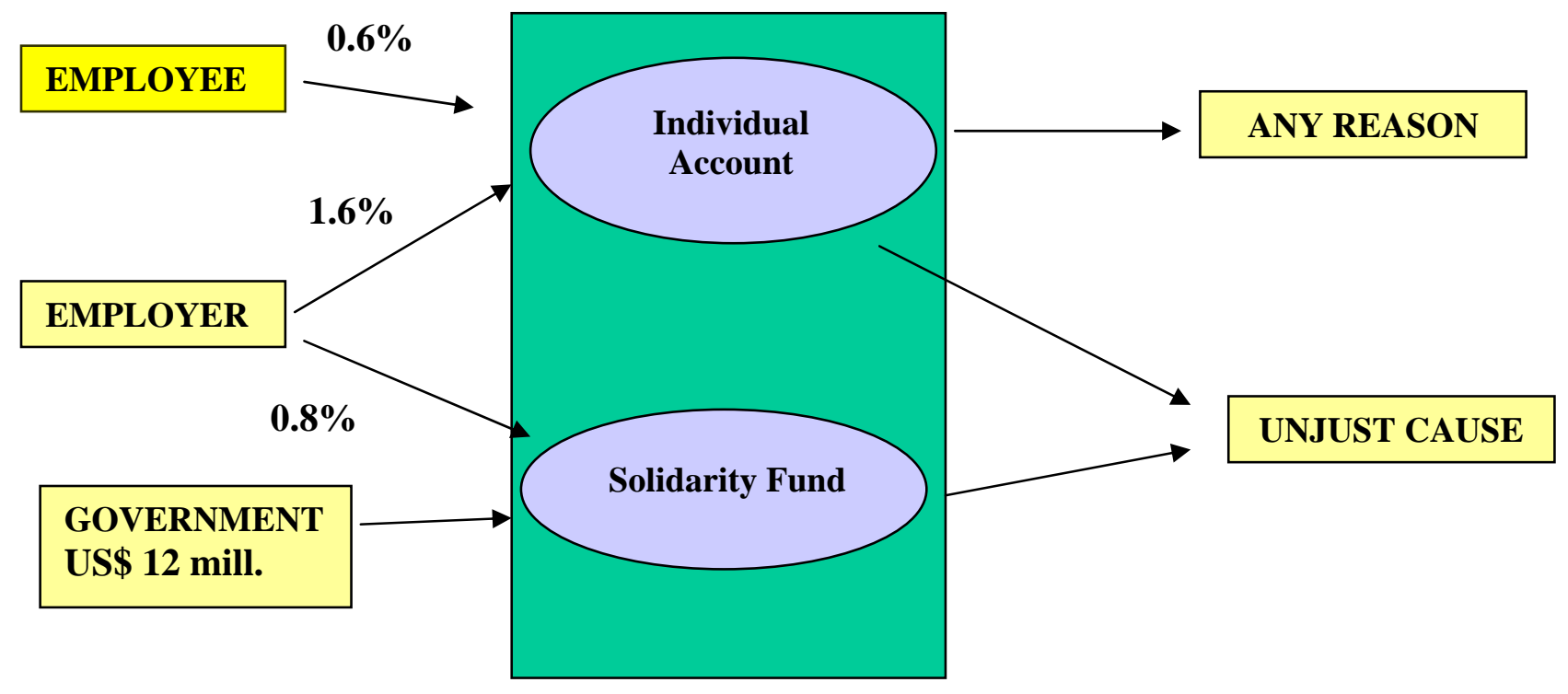


Since 2002, Chile has a new system of unemployment protection. The law regulating the current Chilean unemployment protection system was approved in 2001. The new system is based on a mixture of individual and public funds, funded by contributions from the employer, the employee and the government (See Figure 2). The system covers all paid workers except public employees, domestic workers, apprentices, retirees or minors. The funding comes from contributions from employees $(0.6 \%$ of the average monthly remuneration over the last 12 months, with a ceiling around US\$2,000 monthly) and employers (2.4\% of the average monthly remuneration over the last 12 months, with a ceiling around US\$2,000 monthly). The employee contributions are limited to 132 months in each employment. ${ }^{11}$ The employer contributions can be deducted from payment of compensation for unjust or economic dismissal. The employer deducts and deposits employee's contributions plus part of his contribution (1.6\% of monthly remuneration) in an "Individual Unemployment Account". There are penalties for failure to comply. The rest of the employer contribution (0.8\%) is deposited in a Solidary or Common Unemployment Fund. The Government contributes to the Solidary Fund with an annually fixed amount of around US \$8.8 million. In case of unemployment, the individual will receive unemployment insurance from his individual account. Any reason for unemployment is valid, including dismissal for economic reasons, retirement, disability or voluntary quitting. This is not withstanding other compensations the worker may have a right to such as severance payments. The main characteristics of the payments are:

O Limited payments

o Decreasing benefits with ceilings and minimum benefits

o Requires at least 12 contributions before accessing any benefits.

o Benefits indexed annually.

The length of the benefits depends on the worker's contributions, specifically one month of benefits for each 12 months of contributions, to a maximum of five months. In the case of voluntary or involuntary unemployment, withdrawals occur for up to 5 months, with the amount of benefits decreasing in time and the initial amount depending on the number of years of previous contributions. These payments stop if the individual initiates a new contract. The final withdrawal

\footnotetext{
${ }^{11}$ Term or temporary workers do not have to incur personal contributions. The employer will cover $3 \%$ of the remuneration. These workers will withdraw all funds at the term of the contract.
} 
is for the balance in the individual's account. In the event of death, disability or retirement, withdrawals are for the balance. This system is in place for new contracts (after October 2001), but workers with previous contracts have the option to join.

An important feature of the new system is that it guarantees a minimum amount of unemployment insurance (as defined by the table below) for workers with low income that have not accumulated enough resources in the individual accounts. To this effect, $0.8 \%$ of the employer contributions are deposited in a Solidarity or Common Fund. Unemployed workers that satisfy the requirements (minimum contributions and involuntary unemployment) and have insufficient funds in their account can withdraw from the Common Fund. Payments stop if the worker is not actively looking for employment or rejects (without justified cause) employment with a wage 50\% or more of his last wage. Payments from the Common Fund are a decreasing percentage of the average wage in the previous 12 months, with a minimum and a maximum amount, both decreasing in the length of unemployment. Individual withdrawals from this fund are limited to 2 every 5 years. Total withdrawals from the Common Fund are limited to $80 \%$ of the last monthly balance.

Table 3. Payments of the Chilean Unemployment Insurance

\begin{tabular}{|c|c|c|c|}
\hline $\begin{array}{c}\text { Unemployment } \\
\text { Duration (months) }\end{array}$ & $\begin{array}{c}\text { Minimum } \\
\text { (CLP) }\end{array}$ & $\begin{array}{c}\text { Benefits } \\
\text { (\% average 12 } \\
\text { monthly wages) }\end{array}$ & $\begin{array}{c}\text { Maximum } \\
\text { (CLP) }\end{array}$ \\
\hline $1^{\text {o }}$ & 65,000 & $50 \%$ & 125,000 \\
$2^{\circ}$ & 54,000 & $45 \%$ & 112,500 \\
$3^{\circ}$ & 46,000 & $40 \%$ & 100,000 \\
$4^{\circ}$ & 38,500 & $35 \%$ & 87,500 \\
$5^{\circ}$ & 30,000 & $30 \%$ & 75,000 \\
\hline \hline
\end{tabular}

The administration of the funds is controlled by the Unemployment Fund Administrator (AFC). This entity won the management of the unemployment funds in public auctions for ten years. The seven existing pension funds administrators in Chile own the AFC. They are monitored by the Superintendence of the Pension Fund Administrators. The AFC is responsible for collecting and 
assigning the contributions to the Individual Accounts and the Common Fund, payment of benefits, investment of resources and customer services. The investment structure is regulated according to the norms that rule investments of Pension Funds. The AFC charges an annual commission of $0.6 \%$ on the funds balance (Acevedo, Eskenazi and Pages, 2006). ${ }^{12}$

The new Chilean unemployment protection system combines various features of individual accounts programs with more traditional ones. First, it facilitates worker mobility and job matching because it offers protection from all forms of unemployment, including voluntary unemployment, retirement, disability, and death. This way the worker does not renounce better employment opportunities because of fear of losing previously accumulated benefits. Second, the system may reduce the moral hazard problems typically associated with the existence of unemployment insurance since the worker has to deplete his/her own resources before being able to access the Common Fund. Moreover, there are important restrictions that limit the access to this fund, as well as additional requirements regarding cause of unemployment and availability to work. At the same time, the system still offers some social insurance to workers with low income who may not have accumulated sufficient resources. Sehnbruch (2004) suggests that although the new system does offer better coverage than the previous system, it does not particularly benefit those in more need of income protection (those holding irregular, short term jobs).

However, the Fund has been very successful. By the end of 2010, almost 7 million Chilean workers have joined the new insurance system (See Table 4). Of these, $40 \%$ are young workers (between 18 and 30 years of age), 48\% are prime age workers (between 31 and 50 years of age) and $12 \%$ are mature workers. The value of the fund as of December 2010 is estimated over 3.8 billion US\$, of which the Solidarity Fund accounts for 27\%, more than doubling its participation since 2003. The average (deflated) return of the Unemployment Fund since its inception has been 2.8\% (3.1\% for the Common Fund) and the short term return is even higher at 3.25\% and $4.2 \%$ respectively over the last 3 years. Since the average (deflated) interest rate on deposits for the last three years has been $2.4 \%$, the Fund seems to be a safe investment for the workers. In terms of the

\footnotetext{
${ }^{12}$ On august 2008, a new "Proyecto de Ley" modified the Chilean Unemployment Fund to increase coverage and introduce more flexibility in terms of requisites to access the funds. In addition the new Law allows for more flexibility in the administration of the Funds with view to increase its returns. (See Bersteien et al. in this volume)
} 
stability of contributions, around $60 \%$ of the affiliates hold indefinite work contracts. Therefore, the evolution of the Fund so far strengthens its role as a source of social insurance.

Table 4. The Chilean Unemployment Fund

\begin{tabular}{|c|c|c|c|}
\hline & $\begin{array}{l}\text { Affiliates } \\
\text { (Millions) }\end{array}$ & $\begin{array}{c}\text { Value } \\
\text { (Th. Chilean Pesos) }\end{array}$ & $\begin{array}{c}\text { Value Solidarity } \\
\text { Fund (\%) }\end{array}$ \\
\hline 2003 & 2.2 & 71,481 & $11 \%$ \\
\hline 2004 & 3.2 & 181,533 & $16 \%$ \\
\hline 2005 & 4.0 & 333,911 & $19 \%$ \\
\hline 2006 & 4.7 & 548,914 & $21 \%$ \\
\hline 2007 & 5.3 & 837,581 & $22 \%$ \\
\hline 2008 & 5.8 & $1,182,221$ & $24 \%$ \\
\hline 2009 & 6.3 & $1,526,712$ & $26 \%$ \\
\hline 2010 & 6.7 & $1,974,140$ & $27 \%$ \\
\hline \multicolumn{4}{|c|}{ Real return on the Fund (\%) } \\
\hline & $2010 *$ & 2008-2010* & $2002 *-2010 *$ \\
\hline $\begin{array}{l}\text { Unemployment } \\
\text { Fund } \\
\text { Common Fund }\end{array}$ & $\begin{array}{l}4,11 \\
7,07\end{array}$ & $\begin{array}{l}3,25 \\
4,20\end{array}$ & $\begin{array}{l}2,79 \\
3,14\end{array}$ \\
\hline $\begin{array}{l}\text { Source: (1) Esta } \\
\text { http://www.safp } \\
\text { (2) Investments } \\
\text { http://www.spen } \\
\text { * Annual averag } \\
1 \text { CLP = 0.0019 }\end{array}$ & $\begin{array}{l}\text { cieros Fond } \\
\text { ats/stats/ } \\
\text { bility of the } \\
\text { 573/article- } \\
\text { ember }\end{array}$ & $\begin{array}{l}\text { Cesantia. AFC } \\
\text { mployment Fund } 2010 \\
\text { html }\end{array}$ & Report \\
\hline
\end{tabular}

\section{Colombia}

The Law 50 of 1990 introduced several reforms to the Colombian Labor Code. One of these involved switching from a traditional system of severance payments to one that required the creation of individual reserve funds. The traditional system had several disadvantages. The employer handled the severance fund on which he was required to offer an annual interest rate of $12 \%$. However, since the employer was not required to generate or maintain enough reserves for the event of group dismissals, it was often the case that there were insufficient funds to make the severance payments. Under the new system, the employer deposits into the individual reserve fund 
an amount equivalent to one month of salary per year of work ( $9.3 \%$ of the annual salary). Payment must be settled annually and the fine for those employers who fail to comply with the regulation is equivalent to $12 \%$ of the severance payment. Workers with contracts under the previous legislation could switch to the new system.

Withdrawals for the total amount in the fund are made upon termination of the contract or retirement. In addition, partial withdrawals are allowed under the following circumstances:

- To finance their education or that of a family member. In this case the necessary amount will be deposited directly by the SAFC into the educational institution.

- To acquire, improve or release mortgage of a house.

- To pay the affiliate's valuation property tax.

- The funds can also be pledged to guarantee house loans granted by worker's funds and cooperatives.

The workers may choose any of the existing Sociedades Administradoras de los Fondos de Cesantia (SAFC) or Severance Pay Funds Administrators as depositary of their funds. These are financial institutions, supervised by the Banking Superintendence, whose exclusive purpose is the administration and handling of severance pay. The SAFC's charge 4\% commission for expenses and are required to maintain a solvency margin and to guarantee a return of at least the average return on 3-month treasury bonds. These SAFC are monitored by the Juntas Directivas, which have representatives of both the workers and employers. Investments must be made in accordance with the conditions and limits established by the Banking Superintendence (see Figure 3). 
Figure 3. Colombian Severance Pay Fund Portfolio

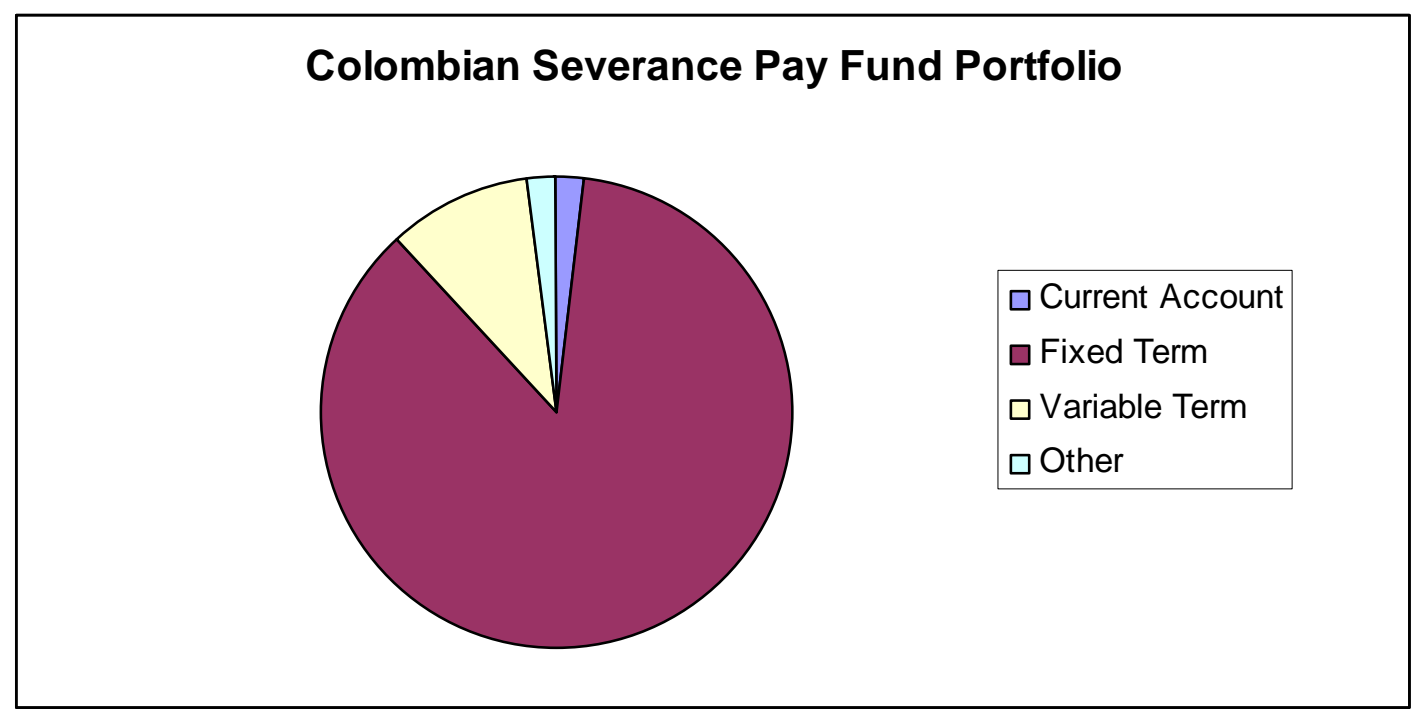

SOURCE: Informes de Coyuntura. Boletin Mensual Superintendencia Bancaria. Colombia

At the end of 2007, almost 4 million workers belonged to the fund. This number has been steadily increasing over the first decade, remaining around 4 million since 2004. Most of the workers affiliated to the Fund (70\%) earn less than two times the minimum wage. The value of the Severance Pay Fund has been increasing over the last several years. Contributions rose considerably during 2002. This was interpreted as a sign of the recovery of the labor market in Colombia, particularly the formal sector. In general, withdrawals are greater than new deposits. However, the liquidity of the fund has not been compromised thanks to the payment of the returns, the sum of new deposits plus returns always being slightly larger than the amount of withdrawals. The positive returns of the Fund encourage voluntary participation. ${ }^{13}$ The real interest rate has stayed around 3\% during 2002, while the nominal rates of return for the Colombian Fund have been declining since 1995. (See Table 5)

\footnotetext{
${ }^{13}$ During 2008 they seem to have experienced some difficulty. Nevertheless, returns are always over the minimum set up by the Banking Superintendence.
} 
Table 5. Evolution of the Colombian Fund

\begin{tabular}{|rccccc|}
\hline & Value of the Fund & \multicolumn{2}{c|}{ Contributors } & \multicolumn{2}{c|}{ 2 year return } \\
& & Total & Voluntary & Nominal & Real \\
& (Millions of COP) & (Thousands) & $(\%)$ & $(\%)$ & $(\%)$ \\
\hline $\mathbf{1 9 9 4}$ & 352 & 1,165 & & -- & \\
$\mathbf{1 9 9 6}$ & 703 & 1,689 & & -- & \\
$\mathbf{1 9 9 8}$ & 1,250 & 1,968 & $12 \%$ & $25 \%$ & $6.5 \%$ \\
$\mathbf{2 0 0 0}$ & 1,865 & 2,274 & $28 \%$ & $17 \%$ & $6.2 \%$ \\
$\mathbf{2 0 0 2}$ & 2,410 & 2,679 & $61 \%$ & $13 \%$ & $5.5 \%$ \\
$\mathbf{2 0 0 4}$ & 4,287 & 2,996 & $48 \%$ & $13 \%$ & $6.4 \%$ \\
$\mathbf{2 0 0 6}$ & 3,740 & 3,711 & -- & $16 \%$ & $11 \%$ \\
$\mathbf{2 0 0 8}$ & 4,013 & 4,478 & -- & -- & $4,43 \%$ \\
$\mathbf{2 0 1 0}$ & 5,598 & 5,430 & -- & -- & $18 \%$ \\
\hline Source: Informes de Coyuntura - Banking Superintendence Colombia & & & \\
1 COP $=0.000526039$ US\$ & & & & \\
\hline
\end{tabular}

\section{Ecuador}

Since November of 2001, Ecuador has a new Social Security Law. The Law regulates a comprehensive social insurance, Mandatory General Insurance (SGO). The SGO includes health, disability, retirement and death, with special provisions for rural/agricultural communities. Contributions to the SGO vary by economic sector, but for most workers amounts to $20.5 \%$ of the monthly wage (11.15\% from the employer and 9.35\% from the employees).

The regulatory organ of the General Insurance is the Instituto Ecuatoriano de Seguridad Social (IESS). It collects the contributions and controls compliance with the law in matters of social security. Within the SGO, there are two varieties of unemployment insurance program. Individuals 40 years of age or younger (and those between 40 and 49 that choose to register), and new workers are covered by the new individual account system. Other workers are covered under the old system of intergenerational insurance. The employer contributes with the equivalent of one 
month's wages per year to an individual account or "Fondo de Reserva" (Reserve Fund). Workers with more than one year of tenure and who are (involuntarily) unemployed have a right to income protection in case of involuntary unemployment. The worker must have a balance equivalent to 48 monthly contributions in the individual account. The amount available is three times the regular monthly wage (averaged over the previous year). In case of retirement, disability or death, the balance accumulated in the individual account will be fully accessible to the workers or his/her inheritors. Workers that are not covered under this program can draw UI benefits under the previous law. ${ }^{14}$

Mandatory savings funds are administered by Provisional Savings Managing Institutions (EDAP's) under the supervision of the Banking Superintendence. The EDAP's also administer the individual Reserve Fund and can offer loans against the amount in the individual Reserve Fund. In 2003 there were around 1.2 million affiliated workers, half of these under fifty years of age. The latest report from the Banking Superintendency (February 2009), values the unemployment fund at 1.4 billion $\$$, with a rate of return of $7.8 \%$.

\section{Panama}

Workers in Panama are entitled to a severance payment of one week's wages per year worked, payable at the end of the labor contract. The employer also has to offer the worker compensation in the case of dismissal without just cause, if the worker leaves the job for justified causes (included economic reasons) or if the labor contract ends of mutual accord. This compensation varies with the worker's tenure according to the scale provided below.

Prior to 1972, the Labor Code established that these payments were a liability of the firm, but it left the management of it to the employer. This created the usual moral hazard problem for the firms described above, leading to bankruptcy and liquidity problems in the case of substantial dismissals. After the new Labor Code became effective in 1972, the employer is required to deposit each trimester the corresponding fraction of the worker's severance payment, plus 5\% of the corresponding amount he would collect in the case the contract terminates, in a trust fund with

\footnotetext{
${ }^{14}$ Those workers access a common fund in the event of unemployment if they have a mimum of 60 non-consecutive contributions to the SGO and after a waiting period of 90 days
} 
a private financial institution (slightly over $80 \%$ of the unemployment fund). Therefore, this part of the fund constitutes a system of individual unemployment accounts, in the sense that the amount is locked in for the workers and cannot be used by the employer. In addition, the worker may make individual contributions to the fund, deposited in a private account, but these are not a substantial part of the fund (Table 7). The fund can be used as a guarantee for loans destined for the purchase of a house.

Table 6. Panama's table of payments

\begin{tabular}{|c|c|c|c|}
\hline \multirow[t]{2}{*}{ Tenure } & \multicolumn{2}{|c|}{ Old Contracts } & \multirow[t]{2}{*}{ New contracts } \\
\hline & Work before 1972* & Work after 1972 & \\
\hline Less than 1 year & 1 week / 3 months & 1 week / 3 months & \\
\hline 1 to 2 years & 1 week / 2 months & 1 week / 2 months & 34 wrooks / vear \\
\hline 2 to 5 years & 3 months & 3 addl Woolcs / voar & 5.4 weens/ yeal \\
\hline 5 to 10 years & 4 months & 3 adal. weeks / year & \\
\hline 10 to 15 years & 5 months & & \\
\hline 15 to 20 years & 6 months & 1 addl. Week / year & 1 week / year \\
\hline More than 20 years & 7 months & & \\
\hline
\end{tabular}

There is no particular institution in charge of managing the severance pay. The employer establishes the trust fund with an approved financial institution of his/her choice. Banks, insurance companies, law firms, and other types of firms can apply to become a depositary of these unemployment funds/trusts, although the majority of them, around 60\%, are banks. However, other types of firms serve most of the workers. The financial institutions in charge of the unemployment trusts offer the market rate of return on the funds; Figure 4 shows the evolution of the rate of returns on the funds help by each type of management firm. 
Table 7. Composition of Panama's Unemployment Fund

\begin{tabular}{|l|c|c|c|c|}
\hline \multicolumn{1}{|c|}{$\begin{array}{c}\text { Accounts } \\
\text { (thousands of Balboas) }\end{array}$} & $\mathbf{2 0 0 1}$ & $\mathbf{2 0 0 3}$ & $\mathbf{2 0 0 5}$ & $\mathbf{2 0 0 7}$ \\
Tenure Fund & 81,041 & 111,435 & 124,476 & 144,438 \\
Unjust Cause Compensation & 11,356 & 10,846 & 17,425 & 21,779 \\
Voluntary Contributions & 544 & 322 & 316 & 146 \\
Sub - Total & $\mathbf{9 2 , 9 4 1}$ & $\mathbf{1 2 2 , 6 0 3}$ & $\mathbf{1 4 2 , 2 1 8}$ & $\mathbf{1 6 6 , 3 6 3}$ \\
Available to Employer & 21,553 & 17,932 & 30,283 & 55,634 \\
Total & $\mathbf{1 1 4 , 4 9 4}$ & $\mathbf{1 4 0 , 5 3 5}$ & $\mathbf{1 7 2 , 5 0 1}$ & $\mathbf{2 2 1 , 9 9 7}$ \\
\multicolumn{1}{|c|}{ Agents (Number) } & & & & \\
Employers & 3,321 & 2,833 & 2,725 & 2,704 \\
Employees & 194,602 & 179,438 & 213,297 & 248,433 \\
Managing Institutions & 20 & 17 & 14 & 11 \\
\hline Source: Banking Superintendency of Panama \\
(1 BALBOA = 1.00000 US \$)
\end{tabular}

Figure 4. Rate of return of Panama's Unemployment Fund.

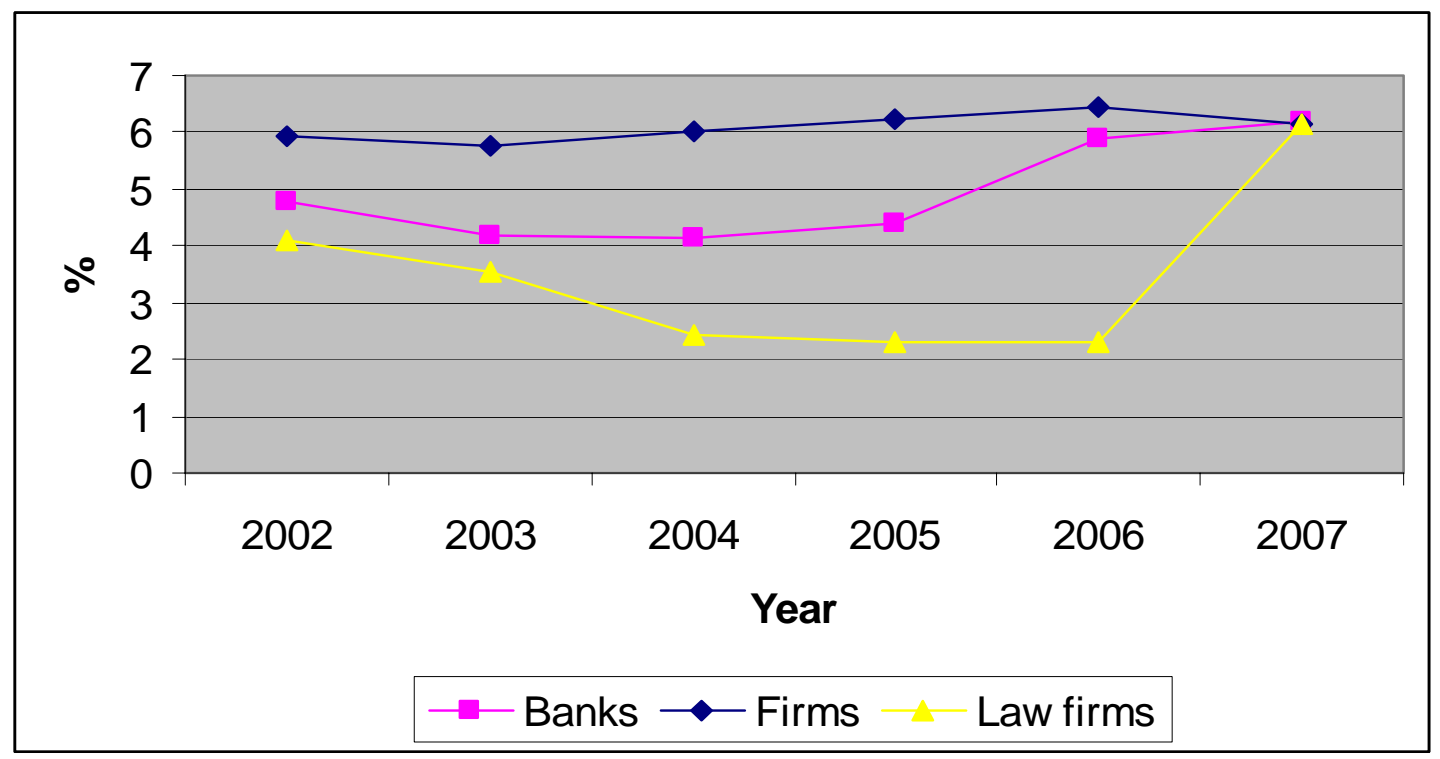

Source: Authors' calculations based on figures from the Banking Superintendency of Panama 


\section{Peru}

In Peru significant labor reforms started in 1991. Prior to this date, the Peruvian Labor Code established a very rigid labor market. What used to be a tenure bonus became the CTS (Compensacion por Tiempo de Servicio, Decreto Legislativo n.650). The text of the Law establishes the CTS as an individual fund to be financed by the employer with a deposit equivalent to 0.5 of the monthly salary payable every six months (deposited in May and December). The system only covers private employees not covered by other special regimes. The worker can choose the financial institution where he wants his fund deposited. Employers and employees can make private arrangements under which the employer becomes responsible for the deposit.

In general, withdrawal of the funds requires proof of dismissal. Originally, however, workers could withdraw $50 \%$ of the funds in the case of an emergency. They could also use up to 50\% of the funds as guarantee of employer's loans or loans from credit unions and savings cooperatives. Nevertheless, the government has authorized additional withdrawals on occasion. For instance, in December 2002 through a Decreto de Urgencia 67-2002, the government authorized the withdrawal of $100 \%$ of the funds to cancel loans and debts incurred with financial institutions. Earlier that year, the Decreto de Urgencia 19-2002 had allowed workers to withdraw the full amount of the deposit made between May and October 2002 to "stimulate domestic demand”. These allowances have continued during 2003 and 2004 and ended in January 2005.

According to the Banking Superintendence, on December 2007, there were over two million CTS deposits valued at 4,769 thousand Peruvian soles (around 1,615 million US\$). Most of these accounts (98\%) are small - for amounts less than 20,000 Peruvian soles - representing only 54\% of the value of the fund. The majority of the deposits are within the banking system (93\%) while the rest are deposited in Savings Cooperatives. Deposits into the savings cooperatives grew at a much faster rate than deposits into the banking system due to the payment of higher interest rates. ${ }^{15} 16$

\footnotetext{
${ }^{15}$ The CTS amounts deposited in the banking system rose by $3 \%$ over the last year, whereas CTS amounts deposited with municipal savings cooperatives rose by $80 \%$. Association Peruana de Consumidores y Usuarios. Boletin de Noticias, August 29, 2008. http://www.aspec.org.pe/

${ }^{16}$ Banks pay, on average 4,5\% (on accounts held in soles) or 2.29\% (on accounts held in dólares), whereas savings cooperatives pay $11 \%$ (on accounts held in soles) y $4.5 \%$ (on accounts held in dólares). La Republica - on line August 29, 2008 http://www.larepublica.com.pe/content/view/220336/484/
} 


\section{Uruguay}

Although, strictly speaking, Uruguay does not have a system of individual accounts for unemployment insurance purposes, we will briefly refer to it because they have the necessary infrastructure (individual accounts) to implement such a system with relative ease. As in Ecuador, the Banco de Prevision Social administers a comprehensive social insurance program that includes medical, life, retirement, disability and unemployment. Approximately one half (7.47\%) of the total employee contributions (15\%) is deposited in a private account. Employers contribute an additional $12.5 \%$ of payroll and the government finances any deficit from tax revenue. This individual account can only be accessed in the event of retirement, permanent/transitory disability or death. The current unemployment protection system in Uruguay, however, does not rely on this comprehensive insurance scheme, but on a traditional UI system. ${ }^{17}$

\section{Venezuela}

Venezuela's Labor Code dates from 1997. Workers (after 3 months of service) have the right to a severance package equivalent to 5 days of pay per month worked. There is an additional 2 days of pay per year after the first year up to a maximum of 30 days. The worker may choose one of the following three forms of receiving the severance fund: either as an individual account, as an individual trust fund, or as an individual account registered in the firm's accounting records. The employer makes monthly deposits into the selected type of account. The return on the trust funds or individual accounts deposited in financial institutions is the market rate. For funds deposited with the firm, the employer has to pay the average rate established by the Central Bank. If the employer fails to make these deposits (to deposit the funds as requested by the employee), he has to pay a rate on the amount owed (not deposited as requested) determined by the Central Bank.

The fund is available to the worker upon termination of the contract, although access is granted to the annual returns yielded by the deposit. The worker has also the right to advance notification of

\footnotetext{
${ }^{17} \mathrm{UI}$ in Uruguay covers employees from the private sector who had been (formally) employed for at least 6 months during the 12 months prior to becoming unemployed. For workers receiving dayly or hourly wages, the requirement is to compute 150 of these wages or 6 minimum wages during the period. Qualified unemployed workers receive $50 \%$ of the average (over the last six months) monthly wages for a maximum period of six months. Refusal of available work without legitimate cause ends unemployment assistance.
} 
dismissal, ranging from one week (after one month's tenure) to 1 month (after one year's tenure). If the employer omits the advance notification, he will pay the corresponding amount of salary at the time of dismissal.

As it is often the case with other UISA systems, partial withdrawals are allowed to finance certain investments. In this case, an employee can obtain a loan of up to $75 \%$ of his/her severance fund to pay for the purchase or financing of a home, his/her education or that of a family member or the individual's or the family's health expenses.

\section{Outcomes of UISA's}

Table 8 offers a summary of the performance of the funds in different countries. Some programs have only limited or almost no information available (Ecuador, Uruguay). Other programs are limited (Argentina) and no information could be found on their operation. In some cases (Brazil), information on the number of beneficiaries is not available.

UISAs in Latin America are typically small, except for the cases of Chile, with 3,2 million contributors by the end of 2009, approximately $50 \%$ of the employed population, and Brazil. In other countries, the low coverage reflects in part the extent of the informal economy. Average balances held in the individual accounts usually exceed minimum monthly wages. However, this may be a poor indicator of the performance of the funds in terms of income protection since, with the exception of Chile, no program guarantees minimum payments.

Although the programs offer some protection agains unemployment risk, they are heavily concentrated among those at lower risk of unemployment (formally employed workers, educated workers, older workers). Bernstein et al (2010) show that, for the Chilean case, the estimated median benefit for older and more educated workers is between 3 and 5 times that of younger, uneducated workers. This is similar in Brazil, where the majority of the FGTS' beneficiaries are above the 50-th percentile of the income distribution (Barros, Courseil and Foguel, 2001; Carneiro, 2003). In Brazil, this could be a consequence of poor past performance of the Funds which forces low income workers in particular to try to access their accounts as often as possible 
to avoid important losses in the purchasing power of their savings. However, the Brazilian Fund has an important redistributive role in the way it is managed. A substantial part of the fund is devoted to alleviating the housing deficit in Brazil and to sanitazion and urbanization projects, which mainlny benefits the low income population. Further, a complementary credit system linked to funds saved overwhelmingly benefits low income workers. In 2006, 89\% of the beneficiaries of the credit system were workers with less than 5 minimum wages in their accounts. ${ }^{18}$

The performance of the funds has been volatile, reflecting the instability of Latin American financial markets. This problem has been particularly acute in Brazil. The FGTS has been poorly managed by the government. Initially, the government guaranteed an interest rate on the accumulated funds to maintain the real value of the Fund. These interest rates were dependent on the length of the labor relationship and varied from 3\% for employees with tenure of less than two years, to $6 \%$ for employees with more than ten years of tenure. During the 1970's various regulations influenced these interest rates, which were finally reduced to $3 \%$ for all deposits initiated after 1970. These changes complicate the calculation of the return on individual deposits, since deposits made at different times and for individuals with different tenures will have different associated interest rates. Exploration of the returns on the deposits involves two main issues. On the one hand, hyperinflation has made it difficult to maintain the real value of the funds. The biggest real losses occurred between 1968 and 1979, when deposits initiated with a nominal interest rate of $3 \%$ depreciated over $40 \%$. Only during the first half of the 1990's were the returns on FGTS accounts enough to compensate for inflation for all account types. On the other hand, the rate of return on the fund also compares poorly with alternative assets. Because the deposits to the Fund constitute a form of forced savings, the returns on these deposits should be compared to those of alternative saving instruments, namely saving accounts. In other countries, like Colombia, the performance of the Severance Fund has been steadily improving over the 1990s. However, with the exception of Brazil, there are no studies comparing the returns on UISA's with other financial assets.

\footnotetext{
${ }^{18}$ One should be careful when discussing the welfare effects of unemployment insurance programs in general, as they can have distortive effects on the distribution of employment (Montenegro and Pagés, 2007)
} 
An additional problem arising from poor fund management and low rates of return on deposits is that, in the presence of liquidity constraints, it creates strong incentives for the worker to try to access the fund. Barros, Corseuil and Foguel (1999, 2001) provide some evidence of the existence of collusive behavior between workers and firms to "label" voluntary quits as dismissals. ${ }^{19}$ In general, these incentives will create higher rates of turnover in the labor market than would otherwise be observed. It is difficult to assess to what extent this is a problem arising from the particular characteristics of the Brazilian Fund or the general performance of the economy or a combination of both. One plausible reason could be that Brazil is the only country, among those offering the unemployment insurance individual savings account system, which makes payment contingent on the type of dismissal, thus creating incentives for this type of collusive behaviour. Yet, the existing structure of the penalty for unjust dismissal in Brazil may be an element affecting (or reinforcing) these incentives. Another possibility is that Brazilian workers may have faced particularly severe credit constraints and therefore had particularly powerful incentives to engage in this collusive behavior. Yet another explanation involves the poor management of the fund, which earned negative real returns for considerable periods of time. Most likely a combination of all of the above shaped this particular effect of unemployment insurance individual savings accounts in Brazil. Therefore, to draw the conclusion that this type of collusion will not persist if, for instance, the fund were made accessible to the worker upon any type of separation might not be correct. Moreover, some of these problems might have different effects in different countries. For instance, credit constraints may generate enough political pressure for the government to allow additional withdrawals from the fund for reasons other than unemployment, as is the case in Peru.

Moving from a system of severance pay to a system of individual accounts is relatively easy in terms of the necessary administrative infrastructure, as the Panama case showed. However, this change highlighted an additional issue that has received some attention in the literature on UISA's, namely that such moving may have an effect on wages. In particular, it opens the possibility that workers and firms respond to the new system by negotiating lower wages to compensate for the

\footnotetext{
${ }^{19}$ The firm dismisses the worker, granting him access to the funds, and the worker renounces the penalty. This type of collusive behavior has become more difficult with the creation of additional penalties for firms in the case of dismissal without just cause, which have to be paid to a common pool and therefore, cannot be "returned" by the employee.
} 
distortionary effects of severance pay regulation. This was not possible under the traditional system because of the firm's moral hazard problem. Kugler (2005) finds evidence suggesting that this is indeed the case. At the same time, Kugler's results suggest that the insurance role of the new severance payment system is very limited and that the individual account system has important effects in increasing turnover rates.

The revisions of the UISA systems that exist in Latin America reveal that, in general, they may increase the flexibility of the labor market without imposing the same high administrative costs and moral hazard problems of traditional Unemployment Insurance systems. The study of individual cases also shows, however, that they pose problems of their own. One of the most important is that they do not seem to be a good source of unemployment protection in the presence of severe liquidity constraints or deficient financial management.

\section{Conclusion}

This paper provides an overview and assessment of the basic features of UISAs in Latin America. Unemployment insurance saving accounts provide an alternative to traditional systems of unemployment insurance, one that seems particularly suitable for developing countries. Their main potential advantages are:

- UISA's may reduce the moral hazard problems associated with the traditional systems, both on the part of the worker and on the part of the firm. If well designed they can provide adequate incentives for workers to return to work and for firms to comply with the payments for dismissal.

- UISA's have the potential to promote flexibility in the labor market by facilitating worker mobility and job matching.

- A system of individual accounts is, in principle, less expensive to implement than unemployment insurance. In addition the transition from most of the actual systems of severance payment seems relatively easy in terms of infrastructure.

- A major caveat is that it is not yet well understood whether or not these programs offer adequate income protection. Evidence suggests that this form of income protection for the unemployed should be complemented with additional forms of insurance. 
The main conclusion from this study is that UISAs seem particularly well suited for developing economies and economies in transition, but with the understanding that assessment of its effects ought to be guided by country specific studies. A key lesson learned from examination of the existent UISAs in Latin America is that any assessment of its effects requires careful country specific analysis. Even though the model implemented in most countries has the same basic features, namely a system of unemployment insurance premiums regularly deposited into individual accounts, it is difficult to extract general conclusions as to its consequences for labor markets. This may be partly because of small differences in implementation, but it may also be due to each country's idiosyncrasies.

In identifying the direction of further research, the particular political and institutional environment of the countries should be taken into account. Ideally, we seek to understand whether differences across countries in the outcomes of UISAs are due to differences in program design and implementation or due to differences in the economies and institutions of these countries. Individual country studies may enable us to see if any general patterns emerge. In addition, despite researcher's efforts, data are not very comparable across countries, which makes country-specific research more effective than cross-country studies.

One of the most pressing matters for research is the ability of UISAs to provide adequate income protection. For some countries, where the extent of the informal or "underground" economy is abnormally large, this implies paying particular attention to the effects of UISAs on the creation of formal employment or to the potential that exists for the administrators of the fund to extract rents from either employers or employees. For other countries, this may be a lesser issue. Other matters, such as ascertaining whether UISAs are contributing to increasing inequality by eliminating the role of social insurance in protecting against unemployment risk, might be more relevant for them. In any of these cases, we ought to consider the alternative income protection programs that are available in each country.

Additionally, the labor market effects of implementing UISA's should be more thoroughly examined. Particularly important, although by nature it is a difficult task, is to understand the 
effects of UISA's on the extent of the informal economy. In addition, the problem of collusive behavior between firms and workers to reduce wages should be considered.

One of the objectives of this paper is to summarize the basic features of UISA systems and examine evidence relating to the performance of these arrangements. This type of assessment can help to identify desirable directions for reform. While such identification may be necessary to bring about change, it is typically not sufficient. Political constraints often make it difficult to move in the desired directions, even when there is general agreement on the problems associated with the current system.

Overall, UISAs have the potential of overcoming some of the worst features of traditional systems of unemployment protection, reducing moral hazard, lowering administrative costs (with respect to unemployment insurance), reducing firing costs and avoiding firms' liquidity issues (with respect to severance payments). Theoretically, they are also likely to promote formal labor markets. However, the system needs to be upgraded with additional features if it is to provide adequate coverage. This, in turn, may limit the advantages mentioned before. The overall effect of UISAs, thus, depends on a vast array of specific country characteristics and program parameters. This calls for individualized studies that address the particularities of each country when assessing or evaluating the performance of UISAs. 
Table 8. Analysis of Funds

\begin{tabular}{|c|c|c|c|c|c|}
\hline & $\begin{array}{c}\text { Brazil }^{1} \\
\text { (End 2009) }\end{array}$ & $\begin{array}{c}\text { Chile } \\
\text { (Dec 2010) }\end{array}$ & $\begin{array}{c}\text { Colombia }^{8} \\
\text { (2010) }\end{array}$ & $\begin{array}{c}\text { Peru } \\
\text { (March 2007) }\end{array}$ & $\begin{array}{c}\text { Panama } \\
\text { (2007) }\end{array}$ \\
\hline Number of Accounts (Th.) & 78,700 (active) & 6,673 & 5,430 & 2,000 & 248 \\
\hline \# Accounts / Employed ${ }^{2}$ & 3.58 & $0.50^{9}$ & 0.29 & 0.13 & 0.32 \\
\hline Fund Balance (Mill. US \$) ${ }^{3}$ & 77,094 & 3,800 & 2,967 & -- & 222 \\
\hline Avg Balance (US\$) & 1,840 & 1,640 & 542 & -- & 894 \\
\hline Min. Monthly Wage (US\$) & $277^{4}$ & 24.7 & $208^{5}$ & 117.9 & $142^{6}$ \\
\hline Net Deposits (Th. US \$) & $33,547,510$ & 358,264 & $(-10,872)$ & 1,615 & -- \\
\hline Withdrawals/Deposits & $87.4 \%$ & $39 \%$ & $242 \%$ & -- & -- \\
\hline Average Withdrawal (US\$) & 339 & 21 & 5.87 & -- & -- \\
\hline Rate of Return & $3 \%$ (fixed) & $3.20 \%$ & 12\% (min. guaranteed) & $4.38 \%$ & Market rate $^{7}$ \\
\hline Costs/Commission & - & $0.6 \%$ & $4 \%$ & - & -- \\
\hline \multicolumn{3}{|c|}{$\begin{array}{l}\text { 1. Accounts represent jobs rather than individuals } \\
\text { 2. Employment figures obtained from the oficial statistic institute in each } \\
\text { country. } \\
\text { 3. Nominal dollars. } \\
\text { 4. Average wage, } 2006 \text { information. } \\
\text { 5. Average monthly income. Average Median income is } 121 \mathrm{US \$} \text {. }\end{array}$} & \multicolumn{3}{|c|}{$\begin{array}{l}\text { 6. Minimum wage ranges from } 142 \text { to } 273 \text { US\$ in the Panama/San } \\
\text { Miguelito region for } 40 \text { hour week. } \\
\text { 7.Average interest rate on domestic deposits } 6 \% \\
\text { 8. September } 2010 \\
\text { 9. Active accounts only ( } 3,200 \text { thousands) }\end{array}$} \\
\hline
\end{tabular}


Bibliography

Asociacion Colombiana de Administradoras de fondos de Pensiones y Cesantia (2001, 2002). Boletin Asofondos num. 28. http://www.asofondos.org.co/

Argentina, Decreto Ley 17.258/67.

Acevedo, Eskenazi and Pages (2006), "Unemployment Insurance in Chile: A New Model of Income Support for Unemployed Workers". Social Protection Discussion Paper \#612. the World Bank.

Amadeo and Camargo (1993). "Labor Legislation and Institutional Aspects of the Brazilian Labor Market". Labour, v7, n1, Spring 1993.

Barros, R. and C. Corseuil (2004) “The Impact of Regulations on Brazilian Labor Market

Performance”, in James Heckman and Carmen Pages, eds., Law and Employment: Lessons from Latin American and the Caribbean , NBER Conference Report series, Chicago and London:

University of Chicago Press, pp 273-350.

Barros, Corseuil and Bahia (1999). "Labor Market Regulations and the Duration of Empoyment in Brazil". Institudo de Pesquisa Economica Aplicada. Texto para Discussão n 676.

Barros, Corseuil and Foguel (2001). "Os Incentivos Adversos e a Focalização dos Progamas de Proteção ao Trabalhador no Brasil". Institudo de Pesquisa Economica Aplicada. Texto para Discussão n 784.

Barros, Corseuil and Gonzaga (1999). "Labor Market Regulation and the Demand for Labour in Brazil". Institudo de Pesquisa Economica Aplicada. Texto para Discussão n 656.

Berstein, S., E. Fajnzyber, P. Gana (2011). “The New Chilean Unemployment Insurance System: combining individual accounts and redistribution in a developing country" in this volume

Blanchard, O.J. and Tirole, J. (2008) “The Joint Design of Unemployment Insurance and Employment Protection: A First Pass”, Journal of the Economic European Association, Vol. 6, No. 1, Pages 45-77

Blondal and Pearson (1995), "Unemployment and Other Non-employment Benefits." Oxford Economic Review of Economic Policy, Vol.11, No.1.

Brazil, Lei n5.107 de 13/09/66.

Camargo (2002). "Fake Contracts: Justice and Labour Contracts in Brazil" in Carneiro, Barros, Gill and Blom - org. Making the Brazi's Labor Market work for Everyone. World-BankIPEA Mimeo.

Carneiro (2003). "A poverty profile and functional aspects of the Brazilian labor market", ECLAC , LC/BRS/R.134

Colombia, Ley 50 de 1990. (28/12/90) 
Cortazar, R. (2001), "Unemployment Insurance Systems for Latin America", in Labor Market Policies in Canada and Latin America: Challenges of the New Millennium. Albert Berry, ed. Kluwer Academic Publishers. Pp.97-107.

DeMarco, G. and Rofman, R. "Supervising Mandatory Funded Pension Systems: Issues and Challenges". Social Protection Discussion Paper N. 9817. World Bank

Encla 1999, Direccion del Trabajo. INE

Economic and Social Progress in Latin America. 1996 Report, Special Section: Making Social Services Work, IDB 1996.

Ecuador, Ley del Seguro Social Obligatorio 2001-55, Noviembre 2001

Feldstein M. and D. Altman (2007) “Unemployment Insurance Savings Accounts”, Tax Policy and the Economy Vol. 21, (2007), pp. 35-63

Gil, Haindl, Montenegro and Sapelli (2000). "Has Unemployment Become more Precarious?", in Gill and Montenegro Eds, Readdressing Latin America's Forgotten Reform: Quantifying Policy changes in Argentina, Brazil and Chile, World Bank

Grosh and Glewwe (1995). "A Guide to Living Standards Measurement Study Surveys and Their Data Sets". Living Standards Measurement Survey Working Paper n120. Washington DC: World Bank, Sept 1995.

Heckman and Pages (2000), "The Cost of Job Security Regulation: Evidence from Latin American Labor Markets" NBER working Paper 7773.

Hopenhayn H. (2001) "Labor Market Policies and Employment Duration: The Effects of Labor Market Reform in Argentina". Interamerican Development Bank. Research Network Working Paper \#R-407.

Holzmann Robert, Yann Pouget, Milan Vodopivec and Michael Weber 2011. "Severance Pay Program around the World: Rationale, Status and Reforms". Fully revised paper presented at the International Workshop on Severance Payment Reform: Toward Unemployment, Savings and Retirement Accounts. Laxenburg/Vienna, Nov 7-8 2003. World Bank: Washington DC, mimeo.

Jaramillo and Saavedra (2005), "Severance Payment Program in Latin America". Empirica, Vol. $\underline{32, \text { Numbers 3-4 }}$

Kugler, Adriana D., "Wage-shifting Effects of Severance Payments Savings Accounts in Columbia,” Journal of Public Economics, 89 (2005): 487-500. 2005

Lipsett, B. (1999), "Supporting Workers in Transition: Income Support Programs for the Unemployed in Brazil and Argentina", Mimeo prepared for Gordon Betcherman, Social Protection Group, World Bank. 
Lozoya, N. (1996), "The Economics of the Informal Sector: A Simple Model and Some Empirical Evidence from Latin America", Carnegie-Rochester Conference Series on Public Policy, 45, p.129-62

Mazza, J. (1999). "Unemployment Insurance: Case Studies and Lessons for Latin America and the Caribbean". Interamerican Development Bank. RE2/S02 Technical Study.

MacIsaac and Rama (1997). Determinants of Hourly Earnings in Ecuador: The Role of Labor Market Regulation" Journal of Labor Economics vol.15, n3, pp.136-165.

MacIsaac and Rama (2000). "Mandatory Severance Payment in Peru: An Assesment of its Coverage and Effects using Panel Data". Draft Paper for the World Bank.

Marquez, G. and C. Pages-Serra (1998) "Ties that Bind: Employment Protection and Labor Market Outcomes in Latin America," WP No. 373, Inter-American Development Bank

Mondino and Montoya (2000). "The Effects of Labor Market Regulations on Employment Decisions by Firms: Empirical Evidence for Argentina". Interamerican Development Bank. Research Network Working Paper \#R-391

Montenegro and Pages (2007), "Job Security and the Age-Composition of Employment: Evidence from Chile.” Estudios de Economia vol.34 iss.2 (2007): 109-139

Oliveira, Beltrão, Pasinato and Ferreira (1999). "A Rentabilidade do FGTS". Institudo de Pesquisa Economica Aplicada. Texto para Discussão n 637.

Orszag et Al (1999). "The Impact of Individual Accounts: Piecemeal vs. Comprehensive Approaches" Annual Bank Conference on Development Economics, World Bank

Panama, Codigo del Trabajo.

Pagés, Carmen, and Claudio E. Montenegro (2007), “Job Security and the Age-Composition of Employment: Evidence from Chile.” Estudios de Economia vol.34 iss.2, pp. 109-139

Parsons, Donald O., "Severance Pay Mandates: Firing Costs, Hiring Costs, and Firm Avoidance Behaviors,” mimeo, George Washington University, 2011.

Parsons, Donald O., “The Firing Cost Implications of Alternative Severance Pay Designs” mimeo, George Washington University (March 2010), Available at: http://ftp.iza.org/dp4967.pdf (2010).

Peru, Decreto Supremo n 001-97-TR Texto Unico Ordenado de la Ley de Compensacion por Tiempo de Servicios. (01/03/97).

Peru, Decreto de Urgencia n. 019-2002. Peru, Decreto de Urgencia n. 026-2002.

Programa de Estadisticas y Estudios Laborales (2002) "La Duracion de las Relaciones de Trabajo: la Permanencia en los empleos y la rotacion laboral", Boletin de Economia Laboral 21. 
Reyes Hartley, G., J.C. Van Ours and M.Vodopivec, “Incentive Effects of Unemployment Insurance Savings Accounts: Evidence from Chile”, Chilean Pension Supervising Authority Working paper series number 40, Santiago, Chile, February 2010.

Saavedra, J. and M.Torero, “Labor Market Reforms and Their Impact over Formal Labor Demand and Job Market Turnover: The Case of Peru,” in Heckman and Pagés, eds., Law and Employment: Lessons from Latin America and the Caribbean, Chicago, The University of Chicago (2004): 131-182.

Seguro de Cesantia Chileno (2002). Informe Tecnico. Superintendencia de Administradora Fondos de Pensiones, Santiago de Chile.

Sehnbruch, K. "Privatised Unemployment Insurance: Can Chile's new unemployment Insurance scheme serve as a model for other developing countries?" Mimeo 2004.

Stiglitz, J. Yun, J. (2006) “Integration of Uemployment Insurance with Pension through an Individual Account” Journal of Public Economics, Vol. 89, Issues 11-12, Pp 2037-2067.

Venezuela, Ley Organica del Trabajo. Caracas 1997.

Vodopivec, M. and Raju, D. (2002). "Income Support Systems for the Unemployed: Issues and Options". Social Protection Discussion Paper Series \# 0214, social Protection Unit, Human Development Network, World Bank.

Vroman (2002). "Unemployment Protection in Chile: Draft Report" Report for the World Bank, March 2002. 